\title{
Lessons from UNCITRAL for Reforming the South African Legal Framework Concerning Security Rights in Movable Property
}

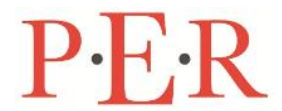

Pioneer in peer-reviewed, open access online law publications

\section{Authors}

Michel M Koekemoer

Reghard Brits

\section{Affiliation}

University of South Africa

University of Pretoria,

South Africa

Email

koekemm@unisa.ac.za

reghardbrits@gmail.com

Date Submission

29 April 2021

Date Revised

10 September 2021

Date Accepted

13 September 2021

Date published

11 January 2022

Editor Ms A Storm

How to cite this article

Koekemoer MM and Brits $\mathrm{R}$

"Lessons from UNCITRAL for

Reforming the South African Legal

Framework Concerning Security

Rights in Movable Property" PER /

PELJ 2022(25) - DOI

http://dx.doi.org/10.17159/1727-

3781/2022/v25i0a10992

Copyright

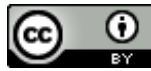

DOI

http://dx.doi.org/10.17159/1727-

3781/2022/v25i0a10992

\begin{abstract}
This article analyses the South African legal framework governing security rights in movable property with a view to inspire law reform. The analysis is based on a comparison of the current South African framework with the UNCITRAL Legislative Guide on Secured Transactions, a soft-law instrument containing international best practice. The problematic aspects of the South African framework benchmarked against the UNCITRAL Guide are: (1) not having a common legal framework that applies equally to all types of (including quasi-) real security transactions; (2) the scope of the current framework not being comprehensive (inclusive) enough; (3) not having an efficient enough method of creating the security right; (4) the current publicity method, particularly concerning special notarial bonds, being overly cumbersome and not providing effective public notice to third parties; and (5) the current enforcement measures potentially not being the most efficient. Finally, regarding each of these problem areas, the article makes proposals on how the South African legislature could reform the current framework into one that is legally efficient and in step with international best practice.
\end{abstract}

\section{Keywords}

Real security law; secured transactions; security rights; notarial bonds; pledge; law reform. 


\section{Introduction}

The South African real security (secured transactions) law framework concerning movable property has remained essentially unchanged over the past few decades. The Security by Means of Movable Property Act (SMPA) ${ }^{1}$ introduced the last major reform of the framework in 1993. Arguably, the South African framework has not kept up to date with global trends and, as a result, the parties to a secured transaction in South Africa cannot reap the optimal economic benefits usually associated with modern and commercially sound secured transactions law. Therefore, in our view, the time has come for a robust law reform initiative whereby international best practice is relied upon as the inspiration to improve South African law in this regard.

The primary source of inspiration used in this article is the United Nations Commission on International Trade Law (UNCITRAL) Legislative Guide on Secured Transactions (UNCITRAL Guide). ${ }^{2}$ Upon comparing the latter with current South African law, we argue that South African real security law should be reformed to the following effect: A registered pledge should be adopted as the security device through which to encumber any individual movable asset or collection of movable assets, thus replacing general and special notarial bonds as well as cession in securitatem debiti. The registration of this pledge should take place in a newly established electronic registry and should, with some exceptions, be used to hypothecate most corporeal and incorporeal movable property. In this article, we justify the various components of this proposal by comparing the current South African law with the global best practice contained in the UNCITRAL Guide.

As explained in Part 2 below, our analysis is structured according to five problem areas identified in the current South African framework. Regarding each of these areas, we extrapolate the ideal approach as recommended by UNCITRAL, determine the extent to which South African law falls short

\footnotetext{
Michel M Koekemoer. BCom LLB LLD. Senior Lecturer, College of Law, University of South Africa. E-mail: koekemm@unisa.ac.za. ORCiD: https://orcid.org/00000002-8880-7399. This contribution is partially based on research done for the first author's doctoral thesis, titled $A$ framework for reforming the South African law of security rights in movable property (UP 2020).

Reghard Brits. BCom LLB LLD. Associate Professor, Faculty of Law, University of Pretoria, South Africa. E-mail: reghardbrits@gmail.com. ORCiD: https://orcid.org/0000-0002-2416-4339.

Security by Means of Movable Property Act 57 of 1993 (the SMPA). UNCITRAL Legislative Guide on Secured Transactions (2007) (UNCITRAL Guide).
} 
and make suggestions regarding how South African law should be reformed to render its secured transactions law framework more legally efficient.

\section{The UNCITRAL Guide: Inspiration for domestic law reform}

To assess the legal efficiency of the South African legal framework applicable to security rights in movable property, we benchmark it against the globally recognised features of a legally efficient secured transactions law framework. The soft-law instruments that embody global best practice in this regard predominantly originate from UNCITRAL. UNCITRAL has prepared several legal instruments concerning secured transactions law, ${ }^{3}$ but the UNCITRAL Guide and ancillary instruments are the most influential. ${ }^{4}$ More recent UNCITRAL instruments include the UNCITRAL Model Law on Secured Transactions (UNCITRAL Model Law), ${ }^{5}$ followed by two instruments that explain the provisions of the UNCITRAL Model Law, namely the UNCITRAL Model Law on Secured Transactions: Guide to Enactment ${ }^{6}$ and the UNCITRAL Practice Guide to the Model Law on Secured Transactions. ${ }^{7}$

In addition to the work by UNCITRAL, prominent regional instruments regarding secured transactions have also been prepared by bodies such as the Organization of American States (OAS) ${ }^{8}$ and the European Bank for Reconstruction and Development (EBRD). ${ }^{9}$ However, in this article, we do not rely on regional instruments directly because many of them are considered precursors to the UNCITRAL Guide. At the same time, the globally accepted principles extrapolated from these regional instruments also find expression in the UNCITRAL Guide. ${ }^{10}$

3 In addition to those cited in subsequent footnotes, see e.g. the United Nations Convention on the Assignment of Receivables in International Trade (2001), which has not yet entered into force.

$4 \quad$ The ancillary instruments include the UNCITRAL Legislative Guide on Secured Transactions: Supplement on the Security Rights in Intellectual Property (2010) and the UNCITRAL Guide on the Implementation of a Security Registry (2013) (the UNCITRAL Registry Guide).

5 UNCITRAL Model Law on Secured Transactions (2016).

6 UNCITRAL Model Law on Secured Transactions: Guide to Enactment (2017).

7 UNCITRAL Practice Guide to the Model Law on Secured Transactions (2020).

8 Two publications deserve mention: the Model Inter-American Law on Secured Transactions (2001) and the Model Registry Regulations (2009).

9 See e.g. the EBRD Model Law on Secured Transactions (1994); EBRD Core Principles for Secured Transactions Law (1997).

10 McCormack Secured Credit and the Harmonisation of Law 102; Akseli International Secured Transactions Law 11. 
The UNCITRAL Guide applies to contractually created security rights (hence, not security rights created by operation of law). Its purpose is to "establish a single comprehensive regime for secured transactions". ${ }^{11}$ The Guide provides a template for a country wishing to reform its legal framework into one that is "modern and efficient". ${ }^{12}$ However, a reforming state need not follow all the recommendations made in the Guide and may deviate from some if there is a sufficient policy reason to do so. The Guide is a normative legal instrument, ${ }^{13}$ meaning that the recommendations are not written in concrete legislative language, but the foundation of the recommendations consists of key policy objectives and fundamental principles that can be used to reform a domestic legal framework. Essentially, the key policy objectives are the general reform objectives recommended by UNCITRAL for a state seeking to reform its system. At the same time, the fundamental principles would form the foundation for the reform. The theory is that, if the fundamental principles are put in place, the key policy objectives will be achieved.

Recommendation 1 of the UNCITRAL Guide lists the key objectives suggested for a state wanting to reform its system as follows: ${ }^{14}$

- the availability of low-cost credit should be promoted by making credit more readily available;

- a debtor must be able to use the full inherent value locked in his or her assets as security;

- the method of creating a security right must be simple yet effective;

- all types of creditors and diverse types of secured transactions must be treated similarly;

- $\quad$ it must be possible to create a non-possessory security right in any kind of asset;

- $\quad$ there should be a general security registry to achieve certainty and transparency;

The purpose statement in ch. 1 of the UNCITRAL Guidelines.

Stewart 2011 Vill $L$ Rev 615. Belgium is an example of a country that has reformed its legal framework following the UNCITRAL Guide. See Dirix and Sagaert 2014 $E P L J 232$ concerning the Belgian reform.

13 Macdonald 2010 Unif $L$ Rev 446.

14 Recommendation $1(\mathrm{a})$ to $(\mathrm{k})$ of the UNCITRAL Guide. 
- the legal rules determining the priority ranking of security rights must be certain and clear;

- $\quad$ efficient enforcement of security rights must be promoted;

- the principle of party autonomy must be respected, allowing the parties extensive flexibility on how to structure their security agreement;

- the interests of the persons affected by a secured transaction must be adequately balanced; and

- harmonisation of laws should be promoted on the assumption that it is mutually beneficial for a state to align its secured transactions law with those of other states. ${ }^{15}$

These key objectives should, therefore, also be the objectives that South Africa should seek to achieve if or when the country decides to reform its current framework into a legally efficient one. In addition to these key objectives, the fundamental principles recommended in the Guide include: ${ }^{16}$

- the legal framework should be comprehensive in scope;

- $\quad$ the framework must be functional and integrated;

- it should be possible to create a security right in a future asset;

- it must be possible to hold a security right in the proceeds of an encumbered asset;

- a clear distinction should be drawn between when the security right is created and when the right becomes effective against all third parties;

- a general security rights registry should be established to give publicity to all security rights;

- it should be possible to take multiple security rights in the same encumbered asset;

- the priority ranking of a security right must be determined on a temporal basis, and using clear and detailed priority rules;

Also see the introduction to the UNCITRAL Guide para 59.

The introduction to the UNCITRAL Guide paras 61-72. 
- the framework of the secured transaction must be facilitative instead of formalistic, meaning that the framework should embrace commercial realities rather than being dogmatic;

- there must be efficient enforcement proceedings, including the extrajudicial enforcement of rights and the realisation of assets; and

- all categories of creditors must be subjected to the same or a similar legal framework.

The main shortcomings of the current South African secured transactions law can be divided broadly into the following categories, each of which relates to one or more of the above-listed key objectives and fundamental principles: (1) there is no common legal framework that applies equally to all types of real security transactions as well as to quasi-real security transactions; (2) the scope of the framework is not comprehensive (inclusive) enough to allow a debtor to utilise the full extent and value of his or her assets as security; (3) the method of creating the security right (as a limited real right) is not simple enough; (4) the publicity method, particularly the registration of notarial bonds, is unnecessarily cumbersome and does not provide effective public notice to third parties; and (5) the current enforcement measures are not efficient enough.

The rest of this article is structured according to the five problem areas identified above. Under each, we compare the current South African situation with the approach recommended by UNCITRAL to determine the extent to which South African law falls short. We also make proposals regarding how the South African framework should be reformed to render it more legally efficient.

\section{A single legal framework covering, as far as possible, all secured transactions}

The ideal of having a single legal framework speaks to two issues in current South African law. The first issue is that, for the most part, different legal principles apply to real security transactions on the one hand and quasi-real security transactions on the other. Real security refers to situations where a limited real right is created in the creditor's favour via something like a pledge, a notarial bond or cession in securitatem debiti, whereas quasi-real security refers to title-based security devices in terms of which the reservation of ownership (title) is used to secure performance. 
The second issue is that multiple security devices must currently be used in South Africa when seeking to create a real security right over different types of movable objects - such as a pledge, a general/special notarial bond and cession in securitatem debiti - which is particularly inefficient when one wants to use different types of assets as security in a single credit transaction. In what follows, we expand on each of these issues concerning the UNCITRAL Guide.

\subsection{Separate legal frameworks for real security and quasi-real security transactions}

The foundational principles underlying real security transactions derive from the law of property, whereas the law of contract is more predominant in quasi-real security transactions. As mentioned above, the latter refers to title-based security devices in which the reservation of ownership is used as the functional equivalent of a security right. Typically, such quasi-real security transactions can take one of two forms: either (1) a creditor/seller/lessor contractually reserves the ownership of an asset, meaning that the transfer of ownership to the debtor/purchaser/lessee is suspended until the latter has fulfilled specified suspensive conditions; or (2) a debtor temporarily transfers the ownership of an asset to the creditor to secure the performance of a contractual obligation.

Some issues associated with the current law applicable to quasi-real security rights include that: (1) a complex transaction wherein a contractual reservation (or transfer) of ownership is utilised could be classified by a court as a simulated transaction, thus not having the legal effect intended by the parties; ${ }^{17}$ (2) the lack of publicity of quasi-real security transactions could prejudice third parties; and (3) because the creditor's security right is in the nature of ownership instead of a limited real right, there are some inconsistencies concerning the respective positions of the parties when the transaction is enforced or when either party goes insolvent.

In the case of a title-based security device that qualifies as an instalment agreement, the seller/creditor's reserved ownership is treated as a real security right proper (hypothec) upon the insolvency of the buyer/debtor. This hypothec secures the seller's claim for any outstanding portion of the

17 A simulated transaction is where parties conclude a transaction in a certain form (for instance a sale) while its true nature is something else (such as a pledge). In such cases, courts will usually give effect to the true nature of the transaction. See Cronje 1979 De Jure 235. Also see Roshcon (Pty) Ltd v Anchor Auto Body Builders CC 20144 SA 319 (SCA), discussed in Sonnekus 2014 THRHR 662 and Freedman 1998 De Jure 400. 
purchase price..$^{18}$ Contrary to the relatively satisfactory nature of the latter arrangement in the case of the buyer's insolvency, the buyer will not enjoy a similar benefit where the seller becomes insolvent. The main problem is that, irrespective of the amount already paid by the buyer, the asset will fall in the seller's insolvent estate. In contrast, the buyer will have a mere concurrent (unsecured) claim for the portion of the purchase price already paid under the instalment agreement. In other words, in the case of the buyer's insolvency, the seller's title-based security is effectively treated like a normal real security right, but the same is not true when the seller goes insolvent. Furthermore, outside of the insolvency context, title-based security devices are not treated like real security rights when, for example, the seller wishes to enforce its rights upon the buyer's default. In the latter event, the seller will remain the owner of the asset and may take possession of and sell the asset without necessarily having to account to the debtor for any surplus. ${ }^{19}$ Although the buyer potentially holds a common-law claim for unjustified enrichment against this seller, he or she is in a much weaker position than would be the case with a debtor under a normal real security right.

Assuming the ideal that a real security framework should apply not only to normal real security rights but also to title-based devices, the UNCITRAL Guide offers two possible approaches. Firstly, under the so-called unitary approach, any rights deriving from both normal and title-based security devices are classified as "security rights", with a title-based security right more specifically being referred to as an "acquisition security right" (the term used in the UNCITRAL Guide)..$^{20}$ Secondly, according to the non-unitary approach, one keeps the separate labels of the different normal and titlebased security devices but attempts to apply a uniform legal framework to both normal security rights and the rights under title-based security devices. ${ }^{21}$

Concerning the unitary approach, all acquisition finance devices complying with the Guide's definition for this term would be treated the same as any other security device under the law unless expressly stated otherwise. In the non-unitary approach, a retention-of-title and a financial lease are

\footnotetext{
18 Section 84 of the Insolvency Act 24 of 1936 (the Insolvency Act).

19 If the transaction is subject to the National Credit Act 34 of 2005 (the NCA), the credit provider has a statutory duty to account to the debtor. See s 127 of the NCA.

20 In the United States of America, article 9 of the Uniform Commercial Code refers to it as a "purchase money security interest".

21 According to Raymond 2011 Elon Law Review 100, allowing these alternatives is an "elaborate attempt at compromise".
} 
mentioned separately from an acquisition security right, but the legal consequences of the rights under these title-based devices would be functionally equivalent to those consequences applicable to other acquisition security rights. Thus, as far as possible, when implementing the non-unitary approach, the same rules applicable to the creation, third-party effectiveness and enforcement should apply in both instances. However, considering both approaches (unitary and non-unitary), the Guide recommends that the security right of the acquisition secured creditor could achieve super-priority above the security rights of other secured creditors, but only if the creditor has taken specific additional steps, such as the registration of its acquisition security right. ${ }^{22}$

To reform South African law, we propose a piecemeal (or incremental) approach initially ${ }^{23}$ and not the immediate adoption of a single framework that would apply to both real security and quasi-security transactions. In our view, the benefits associated with adopting either a unitary or non-unitary approach are not enough to warrant that South Africa adopt a single framework. In the first instance, adopting a unitary approach whereby ownership, when used for security purposes, is reclassified as a limited security right, albeit only for insolvency purposes, would dilute the nature of ownership. Although section 84 of the Insolvency Act effectively reclassifies the reserved ownership of a seller under an instalment agreement as a limited real right in a case of the insolvency of the buyer, this arrangement is limited and does not have an impact on the broader law of property and the general nature of ownership. Indeed, this arrangement applies only to transactions that fall into the specific definition of "instalment agreement" and thus does not extend to all types of title-based security devices. Moreover, section 84 applies only upon the insolvency of the buyer and has no relevance in any other circumstance. Imposing such a reclassification on all title-based security transactions would, in our view, be a too drastic amendment to existing property law. For the time being the deficiencies in the principles surrounding title-based devices can be addressed in ways (mentioned below) that are less drastic than the adoption of a unitary approach.

Unlike the unitary approach, the non-unitary approach does not entail the reclassification of ownership as a limited right but instead adopting uniform rules that would apply to both normal security rights and rights under title-

22 See recommendations 185, 197 and 199 of the UNCITRAL Guide.

23 A similar recommendation was made in Scottish Law Commission 2017 https://www.scotlawcom.gov.uk/files/9215/1361/1360/Report_on_Moveable_Trans actions_-_Volume_2_Report_249.pdf. 
based security devices as functional equivalents. However, it would appear unavoidable that the essence of ownership as the most complete real right, and typically stronger than a limited real right, would be diluted were it to be regarded in general law (not merely in a limited insolvency circumstance) as the functional equivalent of a mere limited real right simply because the right (ownership) is held for credit security purposes. ${ }^{24}$

Arguably, the current popularity of title-based security devices would be reduced if, as we advocate, a legally efficient non-possessory security device were to be introduced as part of the South African framework. Accordingly, before deciding whether to amend the principles of ownership (by adopting either a unitary or a non-unitary approach), it is advisable to first implement a legally efficient non-possessory security device for normal real security rights. Subsequent reform projects might then return to the question of how title-based devices should be treated and, for instance, if changes ought to be made to the nature and content of ownership under such circumstances.

Accordingly, our recommendation concerning the rights in terms of titlebased security devices is not to reclassify these rights as limited "security rights" and to leave this matter to future research. However, specific pressing concerns associated with these title-based devices could be addressed without changing the nature of ownership in these transactions or adopting either of UNCITRAL's recommended approaches. The main concerns are: (1) the lack of transparency because title-based transactions are not publicised; and (2) the unfair position of the buyer under an instalment agreement when the seller becomes insolvent.

Regarding publicity, a possibility, at least for now, could be to allow the voluntary registration of these rights. In time, when it appears that the general security rights registry operates successfully with respect to normal security rights in movable property, one could consider the possible next step of making it compulsory to register all title-based security rights as well. If the latter development is successful, a further step could be to reclassify the ownership rights under all title-based security transactions as "security rights". In other words, we would prefer a natural progression over time towards a unitary approach instead of a once-off drastic legal change.

Concerning the position of a buyer under a title-based security device when the seller enforces his or her rights by repossessing and selling the property,

24 See Brits Real Security Law 181-192 for a discussion of using ownership as a security right in the South African context. 
the current South African legal position is that a buyer has a claim against the seller for any surplus value, based on unjustified enrichment. However, we suggest the creation of a statutory obligation on the seller to account to the buyer for any excess. This would grant the buyer a clear statutory right, rather than one founded in the common law of unjustified enrichment, to pursue a claim against the seller where the latter fails to account to the buyer ${ }^{25}$ Furthermore, we recommend adopting a rule whereby, upon the seller's insolvency, the buyer would have a priority claim to the proceeds of the property to cover any amounts already paid towards the purchase price. ${ }^{26}$

In summary, therefore, we do not recommend at this stage that a single (unitary or non-unitary) approach should be adopted in South Africa whereby all real security and quasi-real security rights are treated the same. However, we recommend adopting a uniform legal framework that would apply to all (or most) normal real security transactions, which is discussed next.

\subsection{A single security device to secure all the obligations under a single secured transaction}

A special notarial bond under the SMPA is the only proper non-possessory security device known to South African law. However, a special notarial bond cannot be registered over all asset categories. The strict specificity principle under the SMPA is mainly responsible for excluding specific asset categories from the scope of such special notarial bonds. ${ }^{27}$ Accordingly, a secured creditor must potentially use a collection of security devices such as a special notarial bond along with cession in securitatem debiti and a general notarial bond to secure the obligations under a single credit transaction. Although it is possible to register a general notarial bond over any type of movable asset, a general notarial bond remains a possessory security device, with the limited real right coming into existence only once the bondholder takes lawful possession of the encumbered assets.

25 See a similar position contained in art 72 of the Belgian Wet tot Wijziging van het Burgerlijk Wetboek wat de Zakelijke Zekerheden of Roerende Goederen Betreft en tot Opheffing van Bepalingen ter Zake (11 Julie 2013) (Belgian Pledge Act of 11 July 2013).

26 Compare s 20(5)(a)(i) of the Alienation of Land Act 68 of 1981, which provides the buyer of immovable property under an instalment agreement with a preference to the proceeds of the property in the case of the seller's insolvency.

27 See further Part 4 below. 
Accordingly, the general notarial bondholder merely has a personal right against the debtor until the lawful transfer of possession occurs. ${ }^{28}$

A debtor can pledge a personal right to his or her creditor using cession in securitatem debiti, but the law applicable to cession is probably also in need of reform along with clarification on several doctrinal questions. ${ }^{29}$ Moreover, because cession is usually not accompanied by publicity, there is a lack of transparency regarding the security right created. The latter reveals a discrepancy in that a security right over tangible movables can be created only by fulfilling the publicity principle (either the delivery or the registration of a special bond), while publicity is generally not required when using intangible movables as collateral.

As a solution to the fragmented and inefficient approach described above, our suggestion is to do away with general and special notarial bonds and cession in securitatem debiti. In their stead, we should establish a single non-possessory security device which, via registration in a public registry, can be used to burden almost any category of movable property. ${ }^{30}$ This device, simply called a "registered pledge", must then have certain specific features, which could include: (1) being capable of covering a specific object as well as a category or fluctuating collection of assets; (2) having a straightforward method to register the pledge; (3) having a registered pledge that can exist in any type of corporeal movable property and most types of incorporeal movable property - unless a category is expressly excluded as a result of a valid policy reason or if a separate specialised regime covers it. Some of these aspects are touched upon in the subsequent parts of this article.

\section{A secured transactions framework with a comprehensive scope}

When considering whether the current framework is comprehensive (inclusive) enough, the general question is whether the law allows a creditor

28 The value of registering a general notarial bond is the protection afforded under s 102 of the Insolvency Act, whereby the general bondholder's claim to the free residue of the debtor's estate ranks higher than other concurrent (unsecured) creditors.

29 For many years, a debate has persisted regarding the correct legal nature of a cession in securitatem debiti, namely whether it is an "out-and-out" (fiduciary) transfer of the personal right or whether the cession should be constructed as creating a pledge of the intangible asset. See in general Brits Real Security Law ch. 5.2. 
to establish a real security right in almost any type of movable property owned (or that will be owned at a future date) by the debtor, but without having to take possession of the property.

\subsection{Synopsis of the scope of the South African legal framework}

To create a non-possessory security right with third-party effect in South African law, the only available option is to register a special notarial bond in compliance with the requirements set out in the SMPA. However, the scope of the SMPA is limited. Section 1(1) of the Act mentions only "corporeal" movable property, which means that special notarial bonds cannot be used to hypothecate incorporeal property. Instead, a separate security device, cession in securitatem debiti, must be used to encumber incorporeal property such as personal rights.

According to section 1(1) of the SMPA, the central requirements for creating a non-possessory security right under the Act are that the notarial bond must be registered in terms of the Deeds Registries $A c t^{31}$ and that the movable property must be "specified and described in the bond in a manner which renders it readily recognizable". The latter requirement speaks to the specificity principle and has been interpreted strictly. The description of the property should be so specific that the exact encumbered asset can be identified with reference to nothing other than the information contained in the bond. ${ }^{32}$

However, the strict application of the specificity principle prevents the SMPA regime from being comprehensive (or inclusive) enough to be in line with modern global trends. The practical result of the current wording of the SMPA is that a special notarial bond under the SMPA cannot be used to create a real security right over the following categories of tangible assets due to the inability to describe them to the satisfaction of the Act: revolving assets (such as stock-in-trade); future assets; proceeds of the encumbered asset; where an encumbered movable is used in the production of a new product (specificatio) or has become mixed with other movables, in the case of solids through commixtio and for liquids through confusio; and movable property that is subsequently attached to immovable property through accessio. $^{33}$

31 Deeds Registries Act 47 of 1937 (the Deeds Registries Act).

32 Ikea Trading und Design AG v BOE Bank Ltd 20052 SA 7 (SCA) paras 11-13. For more detail, see Brits Real Security Law 245-247. 
The scope of the asset categories that can be included under a general notarial bond is comprehensive since such a bond per definition covers all corporeal and incorporeal movable property of the debtor. However, the real security right comes into existence only once the creditor lawfully takes possession of the property. Thus, a general notarial bond does not fulfil the need for a non-possessory security right with third-party effect over any type of movable property.

Therefore, to achieve a secured transactions framework with a comprehensive scope in South African law, it is necessary to expand the categories of movable property that can be used to secure an obligation. As shown above, a significant hindrance to this is the strict specificity requirement currently applicable to the description of the asset encumbered by a special notarial bond in terms of the SMPA.

\subsection{The UNCITRAL Guide applied to issues associated with the South}

\section{African framework}

According to the UNCITRAL Guide, for a legal framework to be comprehensive enough it should include the possibility of using the following assets as security: (1) any type of corporeal and incorporeal asset unless there is a good reason to exclude a specific category; (2) future assets; (3) the proceeds of the original encumbered asset, unless there is a good reason to exclude a specific category, such as certain types of receivables; (4) a mass or a product; ${ }^{34}$ (5) all the debtor's assets, referred to as "all-asset security"; and (6) encumbered movable property that is subsequently attached to immovable property.

\subsubsection{Type of corporeal and incorporeal assets to be included}

The Guide recommends that it be possible to use any type of asset as security unless there is a policy reason for excluding an asset category. Recommendation 4 expressly excludes specific high-value mobile equipment subject either to national law or to an international agreement; intellectual property when taking a security right in this asset contravenes either national laws or treaty obligations; directly- or indirectly held securities; and any payments that arose from financial contracts or foreign exchange transactions. In light of this recommendation, our proposal for a reformed South African framework is that: (1) it should include all types of

34 A mass or product refers to "tangible assets other than money that are so physically associated or united with other tangible assets that they have lost their separate identity"; see recommendation 22 of the UNCITRAL Guide. 
corporeal movable property as part of the framework, unless there is a particular policy reason to exclude an asset category, including those categories listed in the UNCITRAL Guide; and that (2) it should be possible to register a pledge in respect of most types of incorporeal movable property as well, subject to investigating whether and if so how the law of cession should be reformed.

\subsubsection{Extending the security right to a mass, product and attachments}

The Guide recommends a novel approach with regard to allowing a security right to extend to a mass or product and movable property attached to immovable property. According to the Guide, a security right in movable property should extend to these associated assets since excluding them is archaic. Indeed, the Guide's recommendation is in step with the needs of modern commerce. ${ }^{35}$ Although the Guide recommends that the security right should extend to the new product or mass, the creditor's security right should be limited to the value of the encumbered asset before it becomes part of the product or mass. ${ }^{36}$ In essence, the new product or mass is a "replacement" of the original encumbered asset. Concerning the attachment of an encumbered asset to immovable property, as long as the movable property remains identifiable, the Guide recommends that the security right continue to exist despite the movable property being attached to the immovable property and technically losing its separate legal identity. ${ }^{37}$

Arguably the biggest issue with extending the security right to a mass, product or attachment from a South African perspective is the implication that a property right could continue to exist where the originally encumbered property ceases to exist as an independent legal object. Essentially, the Guide's recommendation to extend the security right to a product, mass or attachment challenges the traditional rules of property law but does so to bring the legal framework closer to commercial reality. Therefore, we suggest that South Africa follow the Guide's example regarding the extension of the security right to a mass, product and attachment.

35 The Belgian Pledge Act of 11 July 2013, an example of a reformed legal framework, incorporated this recommendation from the Guide in s 20 concerning a mass and s 18 concerning a product.

36 Recommendation 22 of the UNCITRAL Guide.

37 Recommendation 21 of the UNCITRAL Guide. An example of domestic law that has taken this approach is S 19 of the Belgian Pledge Act of 11 July 2013, which embodies the recommendation of the Guide concerning extending the security right to fixtures to immovable property. 
With respect to attachments, at least two issues could arise when allowing a security right in movable property to continue to exist after the movable property is attached to immovable property. Firstly, South African law currently regards the attached movable property as losing its independent legal existence and forming part of the immovable property. Secondly, there would be a lack of transparency regarding the existence of the security right in the attached movable property if the right were not recorded in the registry applicable to the immovable property. The first issue may be resolved by extending the security right only to the value of the attached movable property while also not allowing the secured creditor to remove the attached movable property. ${ }^{38}$ In this instance, we see no significant issues with disregarding the traditional rules of accession to create a commercially efficient rule on the condition that the movable should remain identifiable. However, the lack of transparency is a matter that would need to be resolved, for instance by adopting a rule that the security right in the attached movable property should be registered in the immovable property register as well or at least endorsed on the title deed of the latter. This possibility is not without precedent in South Africa, and the transparency issue is thus not an insurmountable hurdle. ${ }^{39}$

\subsubsection{Extending the security right to the proceeds of the original encumbered asset}

Regarding the "proceeds" of the encumbered asset, our proposal for the South African framework is similar to the recommendation of the UNCITRAL Guide. Under the Guide, the proceeds of property encompass not only that which most domestic legal systems, including South African law, typically characterise as fruits (natural and civil), but also the proceeds resulting from a disposal or transfer of the encumbered asset. ${ }^{40} \mathrm{It}$ is our proposal to adopt this wider meaning of "proceeds" under the reformed South African secured transactions regime as well. Therefore, we should consider extending the security right not only to the natural and civil fruits of that property but also to any identifiable funds deriving from the sale or transfer of the asset.

\footnotetext{
38 See e.g. the recommendation by Helsen 2015 ERPL 967 in the Belgian context.

39 A comparable example is found in s 31 of the Land and Agricultural Development Bank Act 15 of 2002, which allows for a charge (security right) to be endorsed against the title deed of agricultural land as security for the repayment of funds extended to construct certain movable objects, such as fences, on the land. 


\subsubsection{Extending the security right to future assets}

Moreover, the South African framework should be adapted to make it possible to register a pledge over future assets, as recommended by the Guide. The crisp question is whether registering a right in a future asset will contravene the nemo plus iuris rule. ${ }^{41}$ According to the nemo plus iuris rule, persons cannot transfer more rights than they have. Therefore, the person who creates the limited real right in favour of another person must either be the property owner or the true owner must have granted a ius disponendi to the person who provides the real right. ${ }^{42}$ The nemo plus iuris rule is not contravened if the security right will exist only from the moment when the asset comes into existence. ${ }^{43}$ However, the prior in tempore rule is contravened if the date for determining the priority ranking for a future asset is the date of registration, which would have taken place before the asset came into existence. Nevertheless, as long as there is adequate publicity of this security right in a future asset, the departure from the prior in tempore rule is justified - and not without precedent in South Africa. ${ }^{44}$

\subsubsection{Extending the security right to include an all-asset security}

According to the UNCITRAL Guide, it should also be possible to burden all of the debtor's assets by using what the Guide refers to as an "all-asset security right". ${ }^{45}$ Such an all-asset security right should be able to cover either all of the debtor's movable assets, a category of assets or a fluctuating collection of assets, such as trading stock. Nevertheless, the debtor must be able to dispose of and replace individual objects in the collection "in the ordinary course of its business" due to the commercial reality that a debtor must be able to buy and sell stock to generate an income.

Currently, the closest option in South Africa for creating an all-asset security right is the registration of a general notarial bond. However, this device does not establish a proper non-possessory security right since the bond must first be perfected through taking lawful possession of the property. Therefore, we recommend that the South African framework should be reformed to include the option to create a registered pledge in respect of all the assets or a category or fluctuating collection of assets of the debtor, and

\footnotetext{
$41 \quad$ Nemo plus iuris transferre potest quam ipse habet.

42 Sonnekus 1997 TSAR 154; Sonnekus 1999 Stell LR 399. Also see Muller et al Law of Property 85.

43 Prior in tempore, potior in iure (a right created first in time is first in law).

$44 \quad$ Compare ss 50 and 51 of the Deeds Registries Act in the case of covering bonds that create security from the date of registration even if the debt came into existence only later. 
that registration alone should be sufficient to create the security right - thus without any need to take possession as well. Moreover, suppose a fluctuating collection of assets is pledged in this way, the debtor should be permitted to replace the individual objects in the collection (in the ordinary course of business). At the same time, the security right should persist over the collection as a unit.

\subsubsection{Amending the method to describe the encumbered asset}

A legal framework cannot have a comprehensive scope without having a flexible approach to describing the encumbered assets. If, as we recommend, notarial bonds (both special and general) are replaced with a registered pledge, it should be possible to describe the encumbered asset specifically and generally, as recommended by the UNCITRAL Guide. Indeed, the contemporary idea behind specificity is concerned less with what is identified, and more with what is identifiable. ${ }^{46}$ The recommendation in the UNCITRAL Guide foresees a description standard that allows for the reasonable identification of the encumbered asset. It is clear that this standard is not nearly as strict as that currently contained in the SMPA. Thus, we recommend adopting a more flexible approach in South Africa as well so that the reasonable identification of either a specific asset, a category of assets or a fluctuating collection of assets will be sufficient to create a real security right in that property via registration alone.

\section{A simple process for creating the security right, which right has the essential qualities of a property right}

There must be clarity regarding the point at which a security right is created and the legal nature of that security right at the moment of creation. The Guide recommends clearly separating when the security right is created and when this right becomes effective against all third parties. However, this approach is not presently followed in South Africa. Instead, in South Africa, when a real security right (being a limited real right) is created, it simultaneously becomes effective against third parties when the transaction is publicised via either delivery or registration. Therefore, it is necessary to decide whether the current approach should be continued or whether South Africa should adopt the UNCITRAL recommendation to draw the distinction mentioned above.

$46 \quad$ See Helsen 2015 ERPL 979 and the Belgian approach of favouring flexibility over specificity, which also corresponds to the approach of the United States in art 9 of Uniform Commercial Code. 
In South African real security law, it is trite that a contract alone is not enough to create a property right in an asset, not even one without thirdparty effect. The notion of a contractually created property right with only inter partes effect is strange to South African law. A security contract merely creates a personal right against the debtor, which entails a duty on the debtor to deliver the property or effect registration. Only upon delivery or registration will a property (limited real) right be created and simultaneously receive third-party effect. For example, with special notarial bonds under the SMPA, registration is required to constitute the non-possessory real security right. For general notarial bonds, registration and the subsequent transfer of possession will create a limited real right.

The approach recommended by UNCITRAL (clear separation between creation and third-party effectiveness) would essentially mean that upon concluding the security contract, the creditor will not merely have a personal right against the debtor but also a property right in the asset. However, this property right will have only an inter partes effect before registration. The Guide provides a few reasons for this approach. The first justification is that the process to create a security right, which allows a creditor recourse to the debtor's asset as security for the debt (and not just a personal right against the debtor), must be quick and straightforward. It would indeed be quick and straightforward to create a security right, which is also a property right, merely by entering into a security agreement. However, as suggested by the Guide, the contractually created property right would protect the interest of a secured creditor against acts of the debtor alone, not those of third parties (until publicity occurs). In our view, providing a secured creditor with recourse against the encumbered movable property but not having this right enforceable against third parties is not enough to justify amending how a security right is created under current South African law. Since the notion of an inter partes property right is unknown (and possibly unnecessary) in South Africa, we do not think that it would be wise to introduce it at this time without further investigation.

Another justification forwarded by UNCITRAL is that the separation approach would allow the inclusion of rights under title-based security devices in a unitary or non-unitary secured transactions law framework rights created via contract alone (no publicity). However, since we do not propose adopting either the unitary or non-unitary approach regarding title- 
based security devices at this stage ${ }^{47}$ this justification for the separation approach is not relevant for South Africa.

In light of the unconvincing reasons (at least to the mind of a South African lawyer) for separating between the creation and third-party effectiveness of a security right, we propose that this approach should not be adopted in South Africa at this time. Not only is it foreign to our established principles of property law, but it also does not appear that adopting this approach would serve any meaningful purpose in overcoming the present inefficiencies in the South African framework. Instead, as explained in more detail below, the publicity method itself requires attention more urgently in South Africa.

\section{Registration in a general registry as the primary publicity method}

The globally recognised ideal is to have a commercially sound method of publicising a security right, namely in an electronic, affordable and userfriendly general registry. Also, the framework should encourage the registration of most types of security rights in the same registry to improve the overall level of transparency and certainty. The recommendation made in Part 4 above concerning the adoption of a comprehensive (inclusive) legal framework cannot be achieved if the registration method used in South Africa is not reformed as well.

Two main issues can be identified concerning the current system for registering real security rights in South Africa. Firstly, the registration process with reference to special and general notarial bonds is cumbersome and, secondly, rights in terms of some secured transactions, such as cession in securitatem debiti and title-based security devices, cannot be registered at all.

The Guide's recommendation regarding publicity entails that a country should have an electronic system that can be accessed remotely and requires little to no assistance from registry staff. ${ }^{48}$ Accordingly, a paperbased filing system is not preferred, especially as there is a "time lag" between when a notice is submitted and the confirmation that the record has been captured. ${ }^{49}$ Moreover, the preferred filing method is "notice filing"

\footnotetext{
$47 \quad$ See Part 3.1 above.

48 Recommendation 54 of the UNCITRAL Guide; ch IV of the UNCITRAL Guide para 104 at 175; ch. II of the UNCITRAL Registry Guide para 91 at 35.

49

Chapter IV of the UNCITRAL Guide para 53 at 162.
} 
as opposed to "transaction filing". Notice filing is typically used in a framework with a clear separation between the creation and third-party effectiveness of the security right, hence the recommended framework under the UNCITRAL Guide. Indeed, the filing of a notice provides mere notice that a security right potentially exists; the notice itself is not conclusive proof of the security right. ${ }^{50}$ Conversely, with transaction filing, the filing confirms the existence of a security right. Also, the Guide recommends the possibility of "advance" registration (filing) of a security right, which would entail that a creditor could register a notice before the security right came into existence. ${ }^{51}$ This approach would, for instance, allow for the registration of a security right concerning a future asset.

The UNCITRAL Guide read with the UNCITRAL Registry Guide ${ }^{52}$ provides the overarching principles for an efficient registry. ${ }^{53}$ Firstly, these principles concern the user-friendliness of the registry and require that the legal and operational guidelines of the registry be "simple, clear and certain". Secondly, the design of the registry must strike a balance between being a "fast and inexpensive system" while still guaranteeing the "security and searchability" of the information recorded on the system. The recommendation is to have an electronic system with general public access to the registry and requiring minimal intervention from registry staff. ${ }^{54}$ Importantly also, the legal framework can have a comprehensive (inclusive) scope only if the registry allows an asset description that can be either specific or general, as discussed in Part 4 above.

The registration system for notarial bonds in South Africa is an example of transaction filing. However, notarial bonds must currently be registered in a deeds registry primarily designed for registering rights in immovable property. Moreover, the current deeds registry system is paper-based and operates mainly through human intervention. Three issues can therefore be identified in connection with the current registration system. Firstly, the process is cumbersome and lengthy, ${ }^{55}$ which is mainly attributed to the fact

50 Scottish Law Commission 2017 https://www.scotlawcom.gov.uk/files/1715/ 1361/1309/Report_on_Moveable_Transactions_-_Volume_1_Report_249.pdf para 6.14 at 68. See also Sigman 2008 ECFR 151; Hamwijk Publicity in Secured Transactions Law 265.

51 Article 4 of the UNCITRAL Model Law; recommendation 67 of the UNCITRAL Guide; and recommendation 13 of the UNCITRAL Registry Guide.

52 UNCITRAL Registry Guide.

53 Chapter I of the UNCITRAL Registry Guide para 10 at 7.

$54 \quad$ Chapter II of the UNCITRAL Registry Guide para 91 at 35.

55 The process is also cumbersome due to having to register a notarial bond both where the debtor resides and where it operates its business. Thus, registration in multiple deeds registries might be required. 
that the system is paper-based. At the same time, it also potentially takes more than a week to complete due to several deeds office examiners having to assess the legal validity of the bond document before registration. ${ }^{56}$ Secondly, registration is costly, resulting from the involvement of attorneys (a notary and a conveyancer) with the attestation and subsequent registration of the notarial bond. ${ }^{57}$ Thirdly, registry information is in reality not as freely accessible to the general public as would be necessary to optimally fulfil the purpose of publicity, namely to inform third parties of the existence of security rights.

Our recommendation regarding the reform of South African law is to establish a new general registry for movable property. It should be compulsory to register all real security rights under the newly established registered pledge, thus in the place of special and general notarial bonds and cession in securitatem debiti. Furthermore, one could consider also providing for the voluntary registration of other rights, such as the rights under cession, title-based security devices and possessory pledges. ${ }^{58}$ Eventually, the system could possibly be expanded to provide for the compulsory registration of especially title-based security devices, as mentioned in Part 3.2 above. Registration in the newly established general registry should, in our view, take the form of transaction filing, bearing in mind the recommendation made in Part 5 above that the creation and thirdparty effectiveness of a security right should coincide.

Of course, the detailed particulars and operational platform of the registry would also have to be decided on. We briefly mention two considerations concerning the operation of the platform. The first consideration relates to the cost of establishing the registry. Indeed, the initial cost of establishing a new movable property security rights registry would be high, but when weighed against the cost-saving for creditors going forward, such a high initial cost would be justified, in our opinion. The income to fund the cost of establishment and the operation of the registry should be funded from the registration fees and the fees charged to search for the registry. ${ }^{59}$

56 However, this may change in the foreseeable future. The Electronic Deeds Registration System Act 19 of 2019 was signed into law and will become effective on a date yet to be proclaimed (see GG 42744 of 3 October 2019). The purpose of the new system is to allow the electronic processing, preparation and lodgement of documents with the Registrar of Deeds.

57 Sections 61, 62 and 102 of the Deeds Registries Act prescribe the process.

58 The legal nature of such rights would not be influenced as a result of voluntary registration.

59 Therefore, it would not be an attorney receiving the fees, but the fees to register a security right and conduct searches would go back directly into funding the operation 
The second consideration concerns the transitional arrangements in the case of existing security rights, ${ }^{60}$ namely the real security rights already in existence at the time when the new movable registry regime becomes operational. Following the Guide's recommendation, a security right that was already effective inter partes should remain effective after the new law becomes operational. ${ }^{61}$ However, concerning the third-party effectiveness of the security right, the Guide recommends having a reasonable transition period during which an existing security right must be converted to a security right under the new legal framework. Accordingly, an existing security right remains effective until the earlier of the time such a right would be effective between the parties under the prior law; and the expiration of a period set by the adopting State for the existing right to remain effective. ${ }^{62}$ Nevertheless, the priority of the existing right when converted to a security right under the new law, will be determined with reference to when the existing security right became effective against third parties under prior law. ${ }^{63}$ Ideally, the rights of a South African creditor secured through a registered special or general notarial bond should be converted to a security right under the new law to continue to remain effective, albeit allowing for a transition period during which existing security rights remain effective. Therefore, regarding when such rights must be converted, after consulting with all the role players in the South African credit industry, the legislator must decide on an effective date that is reasonably attainable and which has been widely communicated to all secured creditors. The cost of converting the existing rights would be minimal to the secured creditor, and there would be the added benefit of having a legally efficient security right.

\section{The creditor's enforcement rights must be as broad as is reasonably possible}

The question under this heading concerns the extent to which the current South African framework allows for the extrajudicial enforcement of security rights while incorporating proper safeguards to protect the debtor and third parties with interests in the encumbered property. As South African law stands, both a clause authorising parate executie and one providing for a

of the registry. A similar recommendation was made in Scottish Law Commission 2017

https://www.scotlawcom.gov.uk/files/9215/1361/1360/Report_on_Moveable_Trans actions_-_Volume_2_Report_249.pdf. Chapter $\bar{X}$ I of the UNCITRAL Guide provides recommendations towards the transitional arrangements.

61 Recommendation 230 of the UNCITRAL Guide.

62 Recommendation 231 of the UNCITRAL Guide.

63 Recommendation 232 of the UNCITRAL Guide. 
quasi-conditional sale are valid, thus allowing the contractually agreed-upon extrajudicial enforcement of a right in movable property. In summary, a parate executie clause permits the creditor to sell the encumbered asset without first obtaining a court order. In contrast, a clause regarding quasiconditional sale allows the creditor to take over (purchase) the property at a fair value. In the latter instance, the property's value will be set off against the outstanding debt and the surplus, if any, paid to the debtor. ${ }^{64}$

However, to exercise the rights under either of the clauses described above, the creditor must first obtain possession of the encumbered asset. Presently, unless a debtor voluntarily hands over possession, a South African creditor cannot get possession of the encumbered property without first obtaining a court order, regardless of anything agreed upon in the original contract. This court order can be obtained through an application for summary judgment. Also, in the case of a quasi-conditional sale, there is some uncertainty as to the strength of the debtor's remedy should the creditor fail to pay over the surplus-value. Currently, the remedy would be based on unjustified enrichment under the common law, but, in our view, it would be better to adopt a clear statutory rule.

The UNCITRAL Guide recommends implementing a general enforcement standard: all enforcement measures must be conducted in a "commercially reasonable manner". This general standard serves as a safeguard protecting the debtor's interests during the enforcement process. The Guide attempts to strike an appropriate balance in protecting the interests of both creditors and debtors. The creditor's interests are protected by providing the option of extrajudicial enforcement, but subject to complying with the general standard mentioned above and providing adequate notice to the debtor and other affected parties (hence implementing safeguards to protect the debtor).

UNCITRAL recommends that the creditor should have an automatic right to take possession of the encumbered asset. ${ }^{65}$ However, dispossession must be subject to complying with specific requirements, namely: (1) the secured creditor must provide notice to the debtor, the grantor or another person in possession of the asset of its intention to take possession from the debtor; and (2) the debtor (grantor) must have consented to give the creditor possession, both in the security agreement and again before possession is

64 For more detail on these clauses, see Brits Real Security Law 162-180.

65 Recommendation 146 of the UNCITRAL Guide. This is not the case under current South African law; see Roos 1995 SALJ 169. 
taken. Accordingly, extrajudicial dispossession is allowed but not without consent.

The UNCITRAL Guide also recommends that a creditor should be empowered to take over any encumbered asset in satisfaction of the debt, subject to certain requirements. The creditor must make a proposal to the debtor, after the debtor's default, regarding the creditor's intention to acquire the asset. The creditor's proposal should be sent to: (1) the grantor, the debtor and/or any other person who must perform the secured obligation; (2) a secured creditor who not necessarily holds a registered security right in the asset but has provided written notice of another right in the asset; (3) any secured creditor who registered a security right in the encumbered asset; and (4) any creditor who had possession of the encumbered asset when the current creditor took possession of the encumbered asset. ${ }^{66}$ All parties that receive a notice of the intended take-over must consent before the creditor can acquire the encumbered asset to satisfy the debt. Unfortunately, the Guide makes no recommendation concerning a standard and/or method for determining the fair value of the encumbered asset.

Concerning reforming the South African framework, a general standard, namely enforcement in a commercially reasonable manner, should arguably be implemented in following the Guide's example. Also, we recommend the adoption of a statutory provision that any person who suffers a loss when the secured creditor fails to comply with the statutory duty to act in a commercially reasonable manner should be compensated for such a loss. ${ }^{67}$

The South African concept of parate executie corresponds for the most part to the concept of extrajudicial disposition recommended in the UNCITRAL Guide. Parate executie concerning movable property, where the creditor already has lawful possession, is lawful and constitutionally valid under current South African law. ${ }^{68}$ Where a debtor agreed to parate executie in the original agreement, the debtor does not have to consent to the execution again. ${ }^{69}$ The existing rules surrounding parate executie should remain part of the reformed framework, subject to reasonable safeguards being put in place to protect the debtor. Such safeguards could include that the creditor must notify the debtor that the property will be sold in execution. The method

\footnotetext{
66 Recommendation 157(a) of the UNCITRAL Guide.

67 See a similar provision in s 69 of the Draft Moveable Transactions (Scotland) Bill, 2017.

68 Certain exceptions exist with reference to certain credit agreements subject to the NCA.

$69 \quad$ Scott 2002 THRHR 663; Brits Real Security Law 173.
} 
of execution and the manner of calculating the price must be fair and reasonable. If the debtor did not consent to parate executie in the original agreement, we recommend that subsequent consent (for instance after default) to an extrajudicial sale may be given by the debtor. Either way, the extrajudicial sale should only be permitted if the debtor has consented.

It is already possible under the current South African framework for the secured creditor to "buy" (take over) the asset at a fair value under either a quasi-conditional sale clause in the original agreement or even a postdefault agreement to sell the asset to the creditor. However, this is a contractual arrangement, and the recommendation is to incorporate this right as part of legislation, albeit still requiring that the debtor should consent that the secured creditor may take over the asset. The legislation should also specifically include the creditor's duty to pay any surplus to the debtor.

Currently, a South African creditor cannot take involuntary possession of the encumbered movable property without first obtaining a court order, which naturally delays the process for the creditor. Although the current approach is not the most optimal from the creditor's perspective, the extrajudicial taking of possession without the debtor's cooperation would not be in line with the strong aversion to self-help in South Africa. A compromise might be found in developing an expedited judicial proceeding that could be used to take possession speedily and efficiently. It is not clear that the existing option of summary execution proceedings can fulfil this role optimally, and thus the development of an alternative might have to be investigated. We also recommend, in line with the Guide, that a South African creditor under a registered pledge should have a statutory right to take possession, subject to judicial approval, of course. Therefore, something like a "perfection clause" in the security agreement should no longer be necessary to establish the right to possession.

\section{Conclusion}

The purpose of this article was twofold. Firstly, we highlighted those aspects of the South African legal framework concerning security rights in movable property that must be reformed for the framework to become legally efficient. The second purpose was to suggest ways to reform the South African framework in view of guidance provided by UNCITRAL instruments. The analysis was conducted based on five problem areas.

The main recommendations presented in this article can therefore be summarised as follows: 
The first issue is that South Africa currently does not have a single common legal framework that equally applies to all types of real and quasi-real security transactions. Even though the UNCITRAL Guide recommends adopting a single framework following either a unitary or non-unitary approach, we do not subscribe to this recommendation. Instead, we suggest not amending the South African law concerning title-based security devices, at least for now, but rather addressing the deficiencies associated with titlebased devices. The UNCITRAL Guide also recommends having a clear separation between the creation and third-party effectiveness of a security right. However, the present inefficiencies of the South African framework are not caused by the failure to separate between creation and third-party effectiveness. Accordingly, we recommend continuing with the existing approach of creating and simultaneously affording third-party effect to a real security right at the moment of publicity.

Adopting a framework with a comprehensive scope is an important recommendation in the UNCITRAL Guide. Therefore, we propose heeding this recommendation by amending the South African framework to have a more comprehensive (inclusive) scope concerning the types of assets that can be included under the registered non-possessory pledge. A related issue concerns the legal method used to create a non-possessory security right. Since the current system of registering notarial bonds is legally inefficient, we propose - as recommended by UNCITRAL - establishing a general security rights register through which to give publicity to security rights in movable property.

Regarding the enforcement of security rights, the UNCITRAL Guide recommends permitting extrajudicial enforcement (possession and execution), subject to specific safeguards to protect the debtor's interests and other creditors. However, it is (and probably should remain) impossible in South Africa for the secured creditor to take possession of the encumbered asset without first obtaining a court order. Therefore, we recommend investigating the possible development of expedited judicial enforcement proceedings.

The South African legal framework concerning security rights in movable property must urgently be reformed since it is outdated and unresponsive to the needs of modern commerce. Moreover, the continued lack of reform in line with international best practices could cause the South African framework to be branded as an ineffective legal framework compared to those of other countries. Therefore, although this article does not contain proposed wording for future statutory reform and although more details 
would undoubtedly have to be worked out, the article makes recommendations regarding some of the main features of a legally efficient secured transactions law framework for South Africa.

\section{Bibliography}

\section{Literature}

Akseli International Secured Transactions Law

Akseli NO International Secured Transactions Law: Facilitation of Credit and International Conventions and Instruments (Routledge London 2011)

Brits Real Security Law

Brits R Real Security Law (Juta Cape Town 2016)

Cronje 1979 De Jure

Cronje DSP "Eiendomsvoorbehoud en Besitlose Pandreg" 1979 De Jure 228-235

Dirix and Sagaert 2014 EPLJ

Dirix E and Sagaert V "The New Belgian Act on Security Rights in Movable Property" 2014 EPLJ 231-255

Freedman 1998 De Jure

Freedman W "Nedcor Bank Ltd Absa Bank Ltd 19982 SA 830 (W)" 1998 De Jure 395-401

Hamwijk Publicity in Secured Transactions Law

Hamwijk DJY Publicity in Secured Transactions Law: Towards a European Public Notice Filing System for Non-Possessory Security Rights (LLD-thesis Universiteit van Amsterdam 2014)

Helsen 2015 ERPL

Helsen F "Security in Movables Revisited: Belgium's Rethinking of the Article 9 UCC System" 2015 ERPL 959-1025

Koekemoer and Brits 2020 THRHR

Koekemoer MM and Brits R "Towards Reforming South African Secured Transactions Law: The Value of a Comparison with International and Regional Legal Instruments" 2020 THRHR 528-541 
Macdonald 2010 Unif $L$ Rev

Macdonald RA "A Model Law on Secured Transactions. A Representation of Structure? An Object of Idealized Imitation? A Type, Template or Design?" 2010 Unif L Rev 419-446

McCormack Secured Credit and the Harmonisation of Law

McCormack G Secured Credit and the Harmonisation of Law: The UNCITRAL Experience (Edward Elgar Cheltenham 2011)

Muller et al Law of Property

Muller $\mathrm{G}$ et al Silberberg and Schoeman's The Law of Property $6^{\text {th }}$ ed (LexisNexis Durban 2019)

Raymond 2011 Elon Law Review

Raymond A "Cross-Border Secured Transactions: Ongoing Issues and Possible Solutions" 2011 Elon Law Review 87-107

Roos 1995 SALJ

Roos J "The Perfecting of Securities Held Under a General Notarial Bond" 1995 SALJ 169-179

Scott 2002 THRHR

Scott $S$ "Summary Execution Clauses in Pledge and Perfecting Clauses in Notarial Bonds: Findevco (Pty) Ltd v Faceformat SA (Pty) Ltd 2001 (1) SA 251 (E)" 2002 THRHR 656-664

Sigman 2008 ECFR

Sigman "Perfection and Priority of Security Rights" 2008 ECFR 143-165

Sonnekus 1997 TSAR

Sonnekus JC "Spesiale Notariële Verband, Beskikkingsbevoegdheid en Logiese Vooroordeel" 1997 TSAR 154-163

Sonnekus 1999 Stell LR

Sonnekus JC "Saaklike Sekerheidsreg vir Onsekere Toekomstige Vordering en Sameloop met Retensiereg op Roerende Saak" 1999 Stell LR 397-416

Sonnekus 2014 THRHR

Sonnekus JC "Verdraaiing van Vereistes vir Eiendomsverkryging van Vragmotors Lei Daartoe dat die Pad Byster Geraak Word" 2014 THRHR 662-677 
Stewart 2011 Vill L Rev

Stewart DP "Private International Law, the Rule of Law, and the Economic Development" 2011 Vill L Rev607-630

\section{Case law}

Ikea Trading und Design AG v BOE Bank Ltd 20052 SA 7 (SCA)

Roshcon (Pty) Ltd v Anchor Auto Body Builders CC 20144 SA 319 (SCA)

\section{Legislation}

Alienation of Land Act 68 of 1981

Belgian Wet tot Wijziging van het Burgerlijk Wetboek wat de Zakelijke Zekerheden of Roerende Goederen Betreft en tot Opheffing van Bepalingen ter Zake (Belgian Pledge Act of 11 July 2013)

Deeds Registries Act 47 of 1937

Electronic Deeds Registration System Act 19 of 2019

Insolvency Act 24 of 1936

Land and Agricultural Development Bank Act 15 of 2002

National Credit Act 34 of 2005

Security by Means of Movable Property Act 57 of 1993

Uniform Commercial Code (USA)

\section{Government publications}

Draft Moveable Transactions (Scotland) Bill, 2017

GG 42744 of 3 October 2019

International instruments ${ }^{70}$

EBRD Model Law on Secured Transactions (1994) 70 The UNCITRAL instruments are placed in a chronological sequence not
alphabetical, to show the progression of the development of the instruments. 
EBRD Core Principles for Secured Transactions Law (1997)

Model Inter-American Law on Secured Transactions (2001)

United Nations Convention on the Assignment of Receivables in International Trade (2001)

UNCITRAL Legislative Guide on Secured Transactions (2007)

Model Registry Regulations (2009)

UNCITRAL Legislative Guide on Secured Transactions: Supplement on the Security Rights in Intellectual Property (2010)

UNCITRAL Guide on the Implementation of a Security Registry (2013)

UNCITRAL Model Law on Secured Transactions (2016)

UNCITRAL Model Law on Secured Transactions: Guide to Enactment (2017)

UNCITRAL Practice Guide to the Model Law on Secured Transactions (2020)

\section{Internet sources}

Scottish Law Commission 2017 https://www.scotlawcom.gov.uk/files/ 1715/1361/1309/Report_on_Moveable_Transactions_-

_Volume_1_Report_249.pdf

Scottish Law Commission 2017 Report on Moveable Transactions Volume 1: Assignation of Claims https://www.scotlawcom.gov.uk/files/ 1715/1361/1309/Report_on_Moveable_Transactions__Volume_1_Report_249.pdf accessed 5 March 2018

Scottish Law Commission 2017 https://www.scotlawcom.gov.uk/files/ 9215/1361/1360/Report_on_Moveable_Transactions_-_Volume _2_Report_249.pdf

Scottish Law Commission 2017 Report on Moveable Transactions: Volume 2: Security Over Moveable Property https://www.scotlawcom.gov.uk/ files/9215/1361/1360/Report_on_Moveable_Transactions_-_Volume _2_Report_249.pdf accessed 5 March 2018 


\section{List of Abbreviations}

EBRD

ECFR

EPLJ

ERPL

NCA

OAS

SALJ

SMPA

Stell LR

THRHR

TSAR

UNCITRAL

UNCITRAL Guide

UNCITRAL Model Law

Unif $L$ Rev

Vill L Rev
European Bank for Reconstruction and Development

European Company and Financial Law Review

European Property Law Journal

European Review of Private Law

National Credit Act 34 of 2005

Organization of American States

South African Law Journal

Security by Means of Movable Property Act 57 of 1993

Stellenbosch Law Review

Tydskrif vir Hedendaagse Romeins-Hollandse Reg

Tydskrif vir die Suid-Afrikaanse Reg United Nations Commission on International Trade Law

UNCITRAL Legislative Guide on Secured Transactions (2007)

UNCITRAL Model Law on Secured

Transactions

Uniform Law Review

Villanova Law Review 